\title{
Competing In the Information Economy
}

\author{
Sudesh M. Duggal \\ Northern Kentucky University, \\ Highland Heights, USA
}

duggals@nku.edu

\author{
Sveta Revinova \\ People Friendship University of Russia, \\ Moscow, Russia
}

\author{
sveta@yahoo.com
}

\begin{abstract}
In the information economy, the successful organization will be a sophisticated information-gathering machine that analyzes and manages information flow with the same skill and focus that the industrial company managed work processes. In the information economy, the successful company will be competitive on price and quality as a given, but will also compress cycle time to a minimum. Time compression will become the principle basis for competitive advantage. The emerging business strategies that achieve competitive advantage through time compression are explored in this paper.
\end{abstract}

\section{Introduction}

Success in the information economy will require a phenomenal increase in the productivity of traditional goods and services. The use of Information Technology (IT) allows business organizations of all sizes to realize faster growth and higher profitability than their competitors. Just like during the shift from an agrarian economy to the industrial economy, machines were the key to increase productivity and the power of the machines was used to leverage productivity. In the same way in this new economy, information is the power and IT is the leverage, which will allow power to be dispersed globally in a shorter period of time. A time-based system will also contribute to firm performance (Ireland, 1997). A timebased strategy gains its advantage through good timing in seizing marketplace opportunities quickly. According to Eisenhardt (1989), in a turbulent environment it is important to move quickly in making and implementing strategic decision. The ability to move swiftly in a rapidly changing environment may be the hallmark of many successful firms today. Sheridan (1994) also supports this concept that by adding speed to the marketplace is considered an important competitive weapon for many firms.

Four techniques for implementing a time-based strategy have been suggested. A firm can be 1) first to market; 2) an early follower; 3 ) in step with majority of competitors; and 4) a late follower. A firm that is first to market may earn above-average returns by being the exclusive provider of the product or service before competitors enters the market. These firms may also enjoy strong consumer preferences for products or services because of early identification with the new product. However, the performance of a firm following a first-to-market strategy may be restrained by high research and development and marketing costs for the new product or service. Liberman and Montgomery (1988) suggested that entrepreneurial firms may find it difficult to endure these high levels of risk. Firms that are early followers

Material published as part of these proceedings, either on-line or in print, is copyrighted by Informing Science. Permission to make digital or paper copy of part or all of these works for personal or classroom use is granted without fee provided that the copies are not made or distributed for profit or commercial advantage AND that copies 1) bear this notice in full and 2) give the full citation on the first page. It is permissible to abstract these works so long as credit is given. To copy in all other cases or to republish or to post on a server or to redistribute to lists requires specific permission from the publisher at Publisher@InformingScience.org may enjoy some of the benefits of entering the market early, while avoiding some of the initial risk and cost. Further, an early follower firm may have the opportunity to learn from the response of the market to the products or services when they were first marketed. Although firms which follow a strategy of being "in step with competitors" (also known as a competitive parity strategy) and "late followers" may avoid high R\&D and mar- 
keting costs, their performance may suffer from competitive pressures on pricing and being unable to differentiate products or services from those of competitors. Stalk (1993) suggested that a strategy of competitive parity might not result in high performance for firms competing in today's rapidly changing environment.

\section{The Emerging Strategy}

Increasing the value delivered to the customer has always differentiated growth and profits among competitors. As we move into the information economy, it will become more and more difficult to differentiate on product and cost alone. James Klopman, VP of merchandising at Russell Athletic says companies will have to "think in terms of service and that has to do with information flow" (Maglitta, 1991). Bruce Burgetz (1992) writes that the key to improving customer service lies in effective use of IT. Success relies on acquiring and maintaining good knowledge and experience with customers. IT systems in marketing and sales functions will allow improved timeliness and quality of inventory management and product mix decisions by automatically collecting and analyzing sales data at the point-of-sale. The organization that can collect, analyze and respond to the information in the least amount of time will outperform the competitors in that market. The information holds the power. The management and coordination of that information is the driving force behind the economic change.

The collection, creation and distribution of information is contributing to the importance and increasing dominance of the service sector employee. Even in so called manufacturing companies like HewlettPackard, $75 \%$ of the employees are involved in service functions like MIS, accounting, R\&D, marketing, sales, distribution, engineering and design. The most successful manufacturers today are those with the most extensive service operations (Peters, 1990). The factory of the future will be a sophisticated information collection, analysis, distribution and management system. The ability to gather and analyze all these types of information is leading to new organizational forms. Familiarity with IT was not necessary for a senior level manager to advance. Today, IT is driving the creative destruction process and hence the transformation process as support personnel are self managed and empowered to make decisions based on the information at their fingertips. Today, familiarity with IT and its capabilities is essential for executive advancement. This phenomenon is leading companies to develop a time-based competitive advantage. "The new organization is competitive in cost and quality as a given. It wins by relentless reduction in the time it takes to meet and satisfy unique customer needs" (Nolan, 1991).

\section{The Time-Based Organization}

In the industrial economy, a company succeeded by having superior processes. They had the capability to manage work flows effectively. In the information economy, key capabilities will be speed, innovativeness and the ability to quickly identify and react to changes in the relevant market. Stalk (1992) defines capabilities as, "Any pattern of behavior that relates to a key process that tends to require crossfunctional coordination, resulting in lower cost and higher customer value". Cross-functional coordination is dependent on information flow and IT is the basic tool required to develop that flow. Perhaps the biggest benefit derived from a time-based strategy is the capability to innovate quickly. Stalk (1993) compares fast innovators to slow innovators and reaches this conclusion. Slow innovators search for major breakthroughs. They are pressured to successfully launch completely new products with no mistakes. They are cautious and slow and spend a great deal of time on extensive market research and senior level management approval. The slightest mistake or change can set a project back for months, or even kill it. Fast innovators, on-the-other-hand, meter their exposure to risk by making small improvements based on the customers reaction. Rather than expensive and time consuming market research, prototype products are introduced in a limited way and then refinements are made before the big rollout. 
The fast innovator is much like the fast manufacturer. Minimizing lot size, grouping related processes together, increases throughput and allowing those involved directly with the process to schedule the workflow. Companies soon realize these benefits. Weeding out wasted time eliminates wasted cost. One senior R\&D manager with Hewlett-Packard stated that, "It simply isn't possible to spend as much money in two years as it is in four" (Stalk \& Hout, 1990). The latest technology can be used and sold closer to its introduction. The company gains the reputation as a reliable and responsive innovator. This leads to the opportunity to charge a price premium.

Heads of R\&D in large corporations are everyday faced with managing conflicting priorities--on the one hand, training their people in disciplines and creating new technology and, on the other, developing rapidly a stream of new products for customers. These priorities not only compete for resources but also suggest different organizational structures, timelines, management metrics, and manager's best suited to lead them. Some companies have been experimenting with new ways to manage these conflicting priorities and organizational requirements by asking managers to play new roles, by creating new organizational shapes and styles, by physically housing R\&D people differently, and by selecting different, nonobvious people for senior jobs in R\&D. These experiments have helped these companies accomplish both sets of priorities with less compromise or interference.

For the time-based competitor, cycle time is the staple measurement. Rather than measuring cost, which can be manipulated by any number of accounting conventions, time is universal and constant. The company starts with the big picture, product development or order-delivery, and then breaks it down into smaller pictures and more specialized processes. Any wasted time is eliminated along with its associated cost. Even wasted time in decision making is eliminated by developing better information channels. Time's major advantage as a measurement tool is that it forces analysis down to the physical level. Once the physical activity is laid bare, the right questions can be asked. The answers lead to corrections and improvements in quality and cost. Perhaps the best example of the effect a time-based strategy can have is the success of Wal-Mart. It is not that K-mart did something wrong, it is just that Wal-Mart did something different. Wal-Mart revised the value delivery system from vendor to warehouse to store to customer.

\section{Time-Based Competitiveness}

Time is the top priority. We now live in real time. It's no longer life in the fast lane because every lane is fast. The computer has changed the way we view time. We expect everything to occur at Pentium speed! A time lag causes stress since it is viewed as an unnecessary waste. This is not a matter of immediate gratification; rather delays--such as standing in line--are viewed as something being wrong with the system, and the company that allows it to happen is perceived as not being up to speed! (Graham, 1996). According to Helms (2000), "Like time itself, competitive advantage is a constantly moving target. The most successful firms know how to keep moving, always staying alert and proactive. Today, time represents a powerful source of competitive advantage and includes managing time in production and service delivery, in new product development and introduction, and in sales and distribution". All time-based competition (TBC) efforts use process strategies to reduce one or more of the various types of lead times faced by the company. They are implemented using such tactics as team building, organizational flattening, and flexible manufacturing systems and simultaneous engineering. The key challenge facing any company attempting to implement $\mathrm{TBC}$ is to insure that there is a proper fit between how the company competes in the marketplace, the specific TBC process strategies selected, and the specific implementation tactics used (Carter, 1995). 


\section{Few Examples of Time-Based Competitiveness}

Wal-Mart, a small discount retailer in rural Arkansas, have become the largest retailer in the world and now compete in nearly every major market on the North American continent. Its cost structure is the lowest in the industry, their net profit percent is among the highest, and it continues to grow in sales and earnings at double-digit rates. Wal-Mart achieved and is maintaining its competitive advantage through time-based strategy using IT to tie the vendors, stores, warehouses and customers into a continuous information loop. Managers were trained and given the autonomy to make inventory management and product mix decisions at the store level with the information collected at the point of sale. Finally, Wat Mart insisted that their suppliers play by the new rules of Electronic Data Interchange (EDI) and was able to convince the vendors that the only customer that mattered was the end user of any product sold in their store and that the best way to satisfy that customer was to work together as a team to deliver value. EDI made it possible to react quickly (innovate) to customer needs as measured by sales. The customer perceived this innovation as added value and rewarded Wal-Mart and its suppliers with increasing sales and profits.

Toyota was a pioneer in fast new product development in the 1980s. A shusa, or strong project manager, took a team of functional specialists and developed distinctive, high-quality cars fast. But in the 1990s, several stresses began to cause problems elsewhere in the Toyota system. The number of auto platforms went from 8 to 18 , and volume per model declined. The number of separate engineering specialties (product and process) went from 23 to 48. So there were more inexperienced shusas and many more specialist heads in the system for senior product line executives to coordinate, and each shusa and specialist head had less time to talk with each other. The whole Toyota system had depended on strong communications and working relationships between shusas and department heads. Finally, commonality of components got lost as the number of platforms rose.

Toyota analyzed the R\&D problem as having three dimensions - technology generation, new product development, and product line portfolio coordination - that needed to be managed simultaneously. To solve the problem, Toyota innovated, both new structure and roles. Structurally, the company broke all R\&D resources into three vehicle centers: rear wheel drive, front wheel drive, and utility vans. Each group is self-contained for functional resources and its new car platforms. The company has grown too big to manage as a single whole. The head of each center wears "dual hats"- each oversees all the functions and new car platforms in the center. This way, each center head cannot trade off unfairly either new products or new technology because he is accountable for both: Each center head will have managed both a department and a new car project earlier in his career.

To cut down on the fragmentation of technical disciplines, the number of departments was reduced from 48 to 16, forcing a larger scope and management task on function heads. And shusas were stratified: each experienced, senior shusa is responsible for his own new platform plus one less experienced shusa, who is responsible for another new car, but usually a less complete redesign. All this helps coordination, so there is growing component commonality and better continuity between models. Technology generation is recovering because budgets, oversight and technical boundaries are all less fragmented than before. And the shusa system for fast new car development is still in place; a self-scheduling, crossfunctional team still develops the vehicle.

Chrysler has also innovated roles and structures. The company's top executives are each responsible for both a function like purchasing or marketing and a product line like small cars or vans. Combined with Chrysler's strong platform team leader concept, this again puts the accountability for all key auto activity in the hands of a few people who have to deal with each other to get anything done. Note that it's not a matrix organization - where complexity and trade-offs are all pushed down to middle managers. At Chrysler, the senior people wrestle with all dimensions themselves. Senior people should be the best resolvers of this complexity. 
Also, Chrysler has built a new design center that reinforces the coordination among functions within a team and across teams within a function. Each floor is devoted to one platform, while each department is arranged in a column vertically in the building. This helps day-to-day, hour-to-hour communications within members of a new product platform team, yet still facilitates colleagues in the same function sharing information. They can simply go up and down a stairwell. Physical arrangement matters a lot in R\&D.

The old AT\&T systems' business presents even tougher issues in managing all three aspects of the total R\&D job. Technologies move fast and are shared across many different types of systems and business units such as switching, transmission, etc. And diverse global customers, each with different standards and levels of need, give rise to more kinds of layered, inter-linked projects. Innovative roles, structures, buildings, and so on can take you only so far. Here you have to reconcile the three conflicting needs of R\&D - technology generation, product line coordination, and new product development - by asking more of your people and by looking for something a little different in selecting the people you ask to play senior manager roles in your R\&D organization. This means asking them to operate and manage effectively in a multi-dimensioned organization. This, in turn, means asking them to influence a lot of things they aren't formally responsible for and to receive others' influence on things they are responsible for. All this requires very good people. It won't work without them.

Over the years, AT\&T did foster a culture of interchange among its people. Barriers to information were kept low. Cross-disciplinary communication was rewarded. (In the old AT\&T, the pace was not as fast as today, but equally rich.) Now, in addition, the organization can have four dimensions: product line, technical discipline, customer groups, and geography. The lines of the organization are complex and not always apparent. The vocabulary, too, is richer. AT\&T goes well beyond the 1990s "process revolution" vocabulary of "process," "quality," "customer satisfaction," "teams," etc. AT\&T asks its people to have these as baseline skills and go from there, working across the three or four organizational dimensions simultaneously. Read AT\&T's annual report and you see the most frequently occurring words are "global networks," "media convergence" and "integrated systems." In contrast, its major competitor's annual report focuses on the vocabulary of the process revolution. AT\&T is the champion in big customer systems; the competitor is smaller, standard products.

Finally, to make this work, AT\&T and some other companies that embrace complexity rather than trying to neatly organize it away are screening managers for a different, bigger set of personal attributes today. In addition to a bias for action and a strong focus on the customer and bottom line, these companies are looking for managers who have intuition, an ability to see the big picture, comfort with ambiguity, and high levels of interpersonal/interactive skills. Promotions in R\&D have often not valued these highly. Yet these are what it takes to manage in complex, changing environments. The giant carrier began offer a managed caching service aimed at bus inesses that want their Web content more evenly distributed across the Web to ensure optimal response time based on a site visitor's geographic location.

\section{Time-based Strategy is Important for All Areas of the Industry}

Rosetta Books, LLC has announced that it's offering Agatha Christie's classic mystery And Then There Were None in a special time-based permit edition. Released in conjunction with network publishing software provider Adobe Systems, Inc. and digital distribution services provider Reciprocal, Inc., the ebook is available for download at http://www.rosettabooks.com in a promotional "\$1 for 10 hours of reading" campaign. Once downloaded, the e-book can be read for 10 hours, after which the book's timebased permit will expire and the content will no longer be available. According to the announcement, the publication of the self-destructing e-book demonstrates technology that could revolutionize the publishing industry and help jump-start the nascent e-book market. 
The concept time-based system has mentioned even such areas, as art. "Art in Motion" (AIM), a new, international festival of time-based arts, opened and closed its temporal window at the University of Southern California (USC) on 28 January 2000. Running non-stop at different sites throughout the campus from 9:45 in the morning until 7:30 in the evening the event consisted of numerous screenings, an exposition of interactive and new media works, an audience-generated performance, a public reception, and an awards ceremony. The festival was founded and organized by Janet Owen and Jim Keller. Their goal was to attract responses from different media bases and place them together in one overarching context where time rather than media or genre would determine the admission of an entry.

\section{Time-based Systems Benefit Not Only the Private Companies, but the State Organizations}

A member of the Department of Defense (DoD) is able to gain access to the use of weapons, sates, offices, and other secure systems only through his or her personal characteristics--voice, fingerprint, vein recognition and other attributes. Unknown to many members of the defense industry and DoD is the existence "inside the Beltway" of a hotbed of innovation that is using cutting-edge technologies to bring this vision to fruition. The Falls Church, VA-based DoD Biometrics Management Office (BMO) was established in 2000 as the Department's executive agent to meet the burgeoning demand for rapid, secure, and certified access to information, weapons systems, and facilities in peacetime and conflict. Phillip Loranger, the BMO's director, updated AFJI on DoD's efforts to use the latest and most promising biometrics technology and systems.

Biometrics is the name for automated methods of identifying or verifying the identity of a living person in real time based on that person's physical characteristics or a personal trait. While there are "a lot more than seven areas in biometrics from a DoD-consumable perspective, we are primarily looking at iris, fingerprint, finger and hand geometry, signature, voice recognition, and facial technologies that will be an interface between an individual and a system--which may include an Information Technology (IT) system, a physical security-control mechanism of some kind, a command and control system, and even a weapon system," Loranger said.

\section{Conclusion}

The transformation from the industrial economy to the information economy is forcing business organizations worldwide to examine their business processes and redefine how they will deliver value to their customers. They are discovering that having the best product and the best price isn't enough to guarantee success. Global competition means there may be a number of companies with equal capabilities in product design, manufacturing, marketing and delivery. Success in the information economy requires a company to have an intimate understanding of the customers' needs, and the ability to satisfy that need quicker than the competition. The emphasis on speed is driving organizations that once were separate to cooperate in joint ventures and to develop close ties with IT. These new links not only create a new value delivery system for the customer, they also form a closed loop between customer, producer and vendor that makes it more difficult for outsiders to enter the business. Companies that don't make the IT investments necessary to gather the customer information and enter into joint ventures will be locked out of their markets. IT is the basic tool that business will use to leverage the productivity of the employee to collect, manage and analyze the information required to meet the changing needs and demands of tomorrows customer.

\section{References}

Burgetz, Bruce (1992). Satisfied Business Customers: the business challenge. CMA Magazine, February, p. 10. 
Carter, Phillip L.; Steven A. Melnyk and Robert B. Handfield (1995). Identifying the basic process strategies for time-based competition. Production \& Inventory Management Journal, 36, No. 1, First Quarter, pp. 65-70.

Chen M.J. and D.C.Hambrick (1995). Speed, Stealth, and Selective Attack: How Small Firms Differ from Large Firms in Competitive Behavior. Academy of Management Journal 38, 453-482.

Due, Richard T. (1994). The Productivity Paradox Revisited. Information Systems Management, Winter, 1994, p. 74-76.

Eisenhardt, K.M. (1989). Making Fast Strategic Decisions in High-Velocity Environments. Academy of Management Journal $32,533-576$.

Graham, John R. (1996). New Individualism Shapes Customer Behavior. First Tennessee Bank Business Review, Vol. 6, No. 2, Spring Quarter, pp. 1, 4.

Handfield, Robert B. (1993). The Role of Materials Management in Developing Time-Based Competition. International Journal of Purchasing \& Materials Management, Winter, 1993, p. 2-10.

Helms, Marilyn M. and Lawrence P. Ettkin (2000). Time-Based Competitiveness: A Strategic Perspective. Competitiveness Review, 2000, Vol. 10 Issue 2, P15.

Information Today, Oct2001, Vol. 18 Issue 9, p45, 2p, 1c.

Ireland, R.D., and M.A. Hitt (1997). Performance Strategies for High-Growth Entrepreneurial Firms. In Frontiers of Entrepreneurship Research. Ed. P.D.Reynolds, W.D. Bygrave, N.M. Carter, P.Davidsson, W.B. Gartner, C.M. Mason, P.P.McDougall. Wellesley, Mass.: Babson College, 90-104.

Kauchak, Marty. (2001). Beyond passwords. Armed Forces Journal International, Sep2001, Vol. 139 Issue 2, p24, 2p, 2 c.

Lieberman, M.B., and D.B. Montgomery (1988). First Mover Advantages. Strategic Management Journal 9, 41-58.

Maglitta, Joseph (1991). It's Reality Time. Computerworld, April, p.81-92.

Moozakis, Chuck. (1999). AT\&T plays catch-up in caching. Internet Week, 09/27/99 Issue 782, p19, 2/5p.

Nolan, Richard L. (1991). The Strategic Potential of Information Technology. Financial Executive, July/August, p. 25-27.

Peters, Tom (1990). Prometheus Barely Unbound. Academy of Management Executive Vol.4 No.4, p.70-83.

Sheridan, J.N. (1994). A CEOs Perspective on Innovation. Industry Week (December 19), 11-14.

Stalk, George Jr and Thomas M. Hout (1990). How Time-Based Management Measures Performance. Planning Review, November/December, 1990, p. 26-29.

Stalk, George Jr. (1992). Time-Based Competition and Beyond: Competing on Capabilities. Planning Review, September/October, 1992, p. 27-29.

Stalk, George Jr. (1993). Time and Innovation. Canadian Business Review, Autumn, 1993, p. 15-18.

Upton, N., E.J.Teal, J.T.Felan. (2001). Strategic and Business Planning Practices of Fast Growth Family Firms. Journal of Small Business Management. 39(1), pp 60-72.

\section{Biographies}

Sudesh M. Duggal is Professor of Information Systems at Northern Kentucky University, where he has been since 1979. His teaching interests are Database Management Systems, Management Information Systems, Visual Basic. NET, and ASP.NET. His research interests are in the field of Database Management Systems, Expert Systems, Distance Learning, Curriculum Issues, and E-Commerce.

Revinova Svetlana Yurievna graduated from Moscow Institute of Radio engineering, electronics and automation in 1992. She is senior lecturer in the department of economic-math model system at Peoples' Friendship University of Russia and has been working at PFUR since 1986. Her teaching interests are "Computer science", "Internet", "Data base", and "Information technologies in corporation" and research interest is e-commerce. She is currently working on her dissertation titled "E-commerce in the USA: analysis and tendencies of the development". 